paediatric registrars, especially Drs. S. Mason and N. Rothfield, who shared our interest in this subject; and to Dr. Janet Roscoe, whose collaboration and criticism have been of equal value. One of us (M. C.) is in receipt of a grant from the Beebe Fund.

REFERENCES

Anthony, E. J. (1957). Brit. J. med. Psychol., 30, 146.

Apley, J. (1954). Practitioner, 172, 171.

Bodian, M. (19.52). Ibid., 169, 517.

Stephens, F. D., and Ward, B. C. H. (1949). Lancet, 1, 6. McTaggart, A., and Scott. M. (1959). J. Pediat \$ $\$ 4,762$.

Nelson, W. E. (1959). Textbook of Pediatrics, 7th ed., p. 655. Saunders, Philadelphia.

Pinkerton, P. (1958). Arch. Dis. Childh., 33, 371.

Swenson, O., and Bill, A. H. (1948). Surgery, 24, 212.

Weissenberg, S. (1926). Z. Kinderheilk., 40, 674

Winnicott, D. W. (1953). Proc. roy. Soc. Med., 46, 675.

\section{ACUTE RESPIRATORY INFECTIONS IN CHILDREN}

\section{ISOLATION OF COXSACKIE B VIRUS AND ADENOVIRUS DURING A SURVEY IN A GENERAL PRACTICE}

\section{E. J. C. KENDALL, M.B., M.R.C.P. General Practitioner}

G. T. COOK, M.D.

Public Health Laboratory, Guildford

\section{AND}

DORIS M. STONE, M.D., D.P.H. Public Health Laboratory, Epsom

Respiratory infections are among the commonest illnesses encountered in general practice. Records have shown that their incidence is highest in childhood (Lidwell and Sommerville, 1951 ; Logan and Cushion, 1958). Only a portion of these illnesses have been found to be due to bacteria, and it has long been assumed that the remainder are due to virus infections. With the introduction of tissue-culture methods for viral propagation, it has become possible to test comparatively simply for the presence of certain viruses. HeLa cell cultures, though of only limited value in the isolation of upper respiratory viruses, are easily maintained in the laboratory and were employed in this investigation. This paper reports the results of virological and bacteriological examination of throat swabs from cases of febrile respiratory illness occurring among children in a general practice. Clinical observations were also made. Stool cultures, which might have increased the number of virus isolations, were not carried out. It was hoped that these studies would reveal the aetiology of a proportion of the acute respiratory infections occurring in this group of children.

\section{Materials and Methods}

The population studied were all registered on the National Health Service list of one of us (E. J. C. K.). This general practice is situated in a Surrey town on the south-west fringe of London. All social groups were represented, with a preponderance of clerical and skilled manual workers. Children up to the age of 18 were included in the survey; the age constitution of this group as it was on June 30,1958 , is set out in Table I. During the period of the survey 129 children joined the group and 117 left it.
TABLB I.-Respiratory Infections from June 1, 1957, to December 31. 1958. Age Distribution of Patients Investigated and Principal Virological and Bacteriological Findings

\begin{tabular}{c|c|c|c|c|c|c}
\hline $\begin{array}{c}\text { Birth } \\
\text { Years }\end{array}$ & $\begin{array}{c}\text { No. } \\
\text { in } \\
\text { Group }\end{array}$ & $\begin{array}{c}\text { All } \\
\text { Respiratory } \\
\text { Infections }\end{array}$ & $\begin{array}{c}\text { No. } \\
\text { Investi- } \\
\text { gated }\end{array}$ & $\begin{array}{c}\text { Coxsackie } \\
\text { B } \\
\text { Virus }\end{array}$ & $\begin{array}{c}\text { Adeno- } \\
\text { virus }\end{array}$ & $\begin{array}{c}\text { Str. } \\
\text { pyogenes }\end{array}$ \\
\hline $1939-43$ & 125 & 76 & 8 & 1 & - & 2 \\
$1944-48$ & 170 & 162 & 21 & 4 & - & 2 \\
$1949-53$ & 190 & 290 & 86 & 11 & 3 & 11 \\
$1954-58$ & 110 & 174 & 31 & 4 & 1 & 3 \\
\hline Total & 595 & 702 & 146 & 20 & 4 & 18 \\
\hline
\end{tabular}

The survey extended over the period June 1, 1957, to December 31, 1958. Observations were not made, however, from August 26 to September 25, 1957, from April 17 to May 1, 1958, and from August 25 to September 23, 1958.

Illnesses included in the study comprised those occurring in children who saw their doctor during the first five days of a febrile respiratory infection. Those who developed specific fevers or who were considered on clinical grounds to be suffering from influenza were not included. Symptoms were listed according to an agreed schedule, and the physical findings were recorded in a standard manner. As often as possible, twice-daily temperature readings were made by the parent. A follow-up visit was made one to three days later, or at the end of the illness.

Laboratory Methods.-Two swabs, mounted on wooden applicators, were fixed in parallel in one cork and sterilized together. This composite swab was applied to the tonsillar fossa. One swab was then used for bacteriological examination (D.M.S.) and the other was broken off into $2 \mathrm{ml}$. of Hanks's solution containing penicillin (100 units $/ \mathrm{ml}$.), streptomycin (100 $\mu \mathrm{g} . / \mathrm{ml}$.$) ,$ and neomycin $(50 \mu \mathrm{g} . / \mathrm{ml}$.). This mixture was frozen in solid $\mathrm{CO}_{2}$ snow in a vacuum flask and later held at $-20^{\circ} \mathrm{C}$. until a virological examination was made (G.T.C.).

Virus Examination.-Virus isolations were attempted in HeLa cells grown in Hanks's solution with antibiotics (as above), containing, in addition, $0.2 \%$ lactalbumin hydrolysate (final concentration), $10 \%$ horse serum, and $10 \%$ rabbit serum. For maintenance, $3 \%$ rabbit serum was used.

Amounts of $0.2 \mathrm{ml}$. of fluid were added to each of two tubes of $\mathrm{HeLa}$ cells. Cultures were incubated at $37^{\circ} \mathrm{C}$. and examined every second or third day for 8 to 10 days. At the end of this period blind passages were always carried out, the cultures of the first passage being examined for a further 8 to 10 days before being discarded.

When cell changes occurred neutralization tests were carried out with poliomyelitis and Coxsackie B antisera. Adenovirus was identified by means of a complementfixation test.

Bacteriological Examination.-Immediately on receipt, throat swabs were plated on layered-blood-agar and laked-blood-tellurite plates. Films were made, stained by Gram's method, and examined microscopically. Plates were incubated aerobically overnight and the flora identified by the usual criteria. Colonies of haemolytic streptococci were picked off and tested by Maxted's (1953) bacitracin sensitivity method. Any which proved not to belong to group $A$ were subcultured and their group was identified by Lancefield's technique. For the purposes of this investigation, streptococci other than those belonging to group A were ignored. 
Pneumococci were further investigated only when they. were without doubt the predominant organism on the blood-agar plates. They were subcultured in dextrose broth, if necessary repeatedly, and the smooth suspensions thus obtained were tested by slide agglutination against the only sera available to us, types $1-3$. The investigation was carried out to determine whether, where no other infective agent could be isolated from patients, there was a constant type of pneumococcus present, suggesting that this had an aetiological significance.

\section{Results}

Of 702 acute respiratory illnesses reported among members of the group during the period of study, 146 came within our terms of reference and were investigated. The results are summarized in Table $I$. Coxsackie B3 virus was isolated on 19 occasions (once in association with an adenovirus) and Coxsackie B4 virus from one case; $13.7 \%$ of all cases investigated were thus associated with these viruses. Adenoviruses types $1,2,3$, and 4 were isolated from four cases $(2.7 \%)$. Streptococcus pyogenes was found in $18(12.3 \%)$ of the cases. Poliovirus was not isolated. Thus in $41(28.1 \%)$ of the cases one or more potential pathogens were discovered in association with acute illness. The clinical findings for each group are compared in Table II.

TABLE II.-Principal Symptoms and Signs in Three Groups of Acute Respiratory Illness

\begin{tabular}{|c|c|c|c|}
\hline & $\begin{array}{c}\text { Coxsackie } \\
\text { B Virus } \\
\text { (19 Cases) } \\
\%\end{array}$ & $\begin{array}{c}\text { Str. } \\
\text { pyogenes } \\
\text { (18 Cases) } \\
\%\end{array}$ & $\begin{array}{c}\text { Undifferen- } \\
\text { tiated } \\
\text { Respiratory } \\
\text { Infections } \\
\text { (25 Cases) } \\
\%\end{array}$ \\
\hline 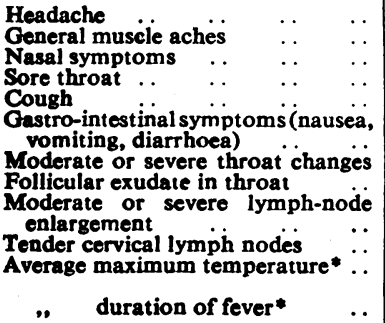 & $\begin{array}{c}84 \\
47 \\
53 \\
58 \\
42 \\
63 \\
47 \\
11 \\
42 \\
21 \\
102 \cdot 1^{\circ} \mathrm{F} \text {. } \\
\left(37 \cdot 9^{\circ} \mathrm{C} .\right) \\
3 \cdot 2^{\text {days }}\end{array}$ & $\begin{array}{c}78 \\
33 \\
83 \\
83 \\
72 \\
50 \\
94 \\
39 \\
67 \\
56 \\
102^{\circ} \mathrm{F} . \\
\left(38^{\circ} \cdot 9^{\circ} \mathrm{C} .\right) \\
2.9^{\text {days }}\end{array}$ & $\begin{array}{c}60 \\
32 \\
84 \\
72 \\
68 \\
56 \\
44 \\
12 \\
28 \\
16 \\
101 \cdot 7^{\circ} \mathrm{F} \text {. } \\
\left(38 \cdot 8^{\circ} \mathrm{C} \text {.) }\right. \\
3 \cdot 2^{\text {days }}\end{array}$ \\
\hline
\end{tabular}

- Refer to 11,13 , and 21 cases respectively.

\section{Coxsackie B Virus Infections}

A variety of illnesses were associated with this virus. In nine cases a short febrile illness began with sore throat and general symptoms of malaise, headache, and shivering. The pharyngeal changes in these cases were moderate or severe. In a further six cases the constitutional symptoms predominated, the throat being either unaffected or only slightly sore, with, at most, slight changes in the upper respiratory tract. Moderately severe myalgia (thoracic or abdominal) occurred in two cases, bronchiolitis in one, and in one further case a moderately severe but transient meningeal reaction dominated the illness. The case in which a double infection occurred with adenovirus and Coxsackie B3 virus is described later under adenovirus infections.

Fever reached to between 100 and $103^{\circ}$ F. (37.8 and $39.4^{\circ} \mathrm{C}$.) in the majority and lasted two to four days. When affected the pharynx was reddened and oedematous, but showed exudate in only two cases. Vesicles were absent, but in two cases greyish plaques 1-2 mm. in diameter without erythema were seen on the soft palate towards the end of the illness. Cervical lymphatic-gland enlargement was never prominent and only slight conjunctival reddening was seen. Bronchiolitis, encountered once, was the sole manifestation of involvement of the lower respiratory tract. In general the physical signs were scanty in relation to the severity of the illness. No complications or relapses occurred, but convalescence was slow for so short a fever.

The following three cases illustrate the range of infection.

Case 1.-A boy, aged 10, awoke in the night of August 12, 1958, with a severe headache, and vomited twice. The next morning he had a frontal headache, was lethargic, disliked the light, and complained of a stiff neck. On examination he was moderately ill with a temperature of $103^{\circ} \mathrm{F} .\left(39.4^{\circ} \mathrm{C}\right.$.). $\mathrm{He}$ had slight redness of the throat and palpebral conjunctivae, gingivit1s, and a moderate neck-stiffness, with pain in the mid-thoracic region on flexion of the cervical spine. There were no abnormal signs in the chest, and the lymphatic glands were not enlarged. In the evening his headache was severe but he had not vomited further. $\mathrm{He}$ was flushed and had a puffy face, but his neck was less stiff. His temperature was $102^{\circ} \mathrm{F} .\left(38.9^{\circ} \mathrm{C}\right.$.). The next day (third day of illness) he was feeling and looking much better and his temperature had become normal. He had only slight pain in the mid-thoracic spine on flexion of the neck. By August 20 he felt fit and energetic and there were no abnormalities on examination. Coxsackie B3 virus was isolated from a throat swab taken on August 13. Serum taken on August 14 neutralized Coxsackie B3 virus to a titre of $1 / 160$, and by August 20 the titre had risen to 1/640. Family History:-His mother and father were not affected. One brother had an acute febrile pharyngitis and herpetic stomatitis, but Coxsackie virus was not isolated from his throat swab. Herpes simplex virus was isolated, however. Another brother remained well. Two months later sera from these two boys neutralized Coxsackie B3 virus to a titre of $1 / 640$ and $1 / 1250$ respectively.

Case 2.-On July 21, 1958, a boy aged 11 suddenly developed pain in the right lower anterior chest, which was worse on deep breathing. He had moderate headache. nausea, sweating, and a poor appetite. His temperature rose to $99^{\circ} \mathrm{F}$. $\left(37.2^{\circ} \mathrm{C}\right.$.), and he slept poorly that night. The next day he felt at first slightly better, with less chest pain, but in the evening the temperature rose to $102.8^{\circ} \mathrm{F}$. $\left(39.3^{\circ} \mathrm{C}\right.$.) and the chest pain returned. On examination at the time the child did not look ill and the only abnormal physical sign was nasal catarrh, which in his case was habitual. There was neither neck stiffness nor abnormal signs in the chest. Coxsackie B3 virus was isolated from a throat swab taken at this time. On July 24 he felt better and the headache and chest pain had gone. On examination the palpebral conjunctivae were slightly red, the nose was blocked, but there were no other clinical signs. His temperature was then $99.5^{\circ}$ F. $\left(37.5^{\circ} \mathrm{C}.\right)$, and thereafter his recovery was uneventful.

Case 3.-On July 11,1958 , a girl aged 10 suddenly complained of headache, feverishness, and a slight soreness at the back of the nose. The next day she felt better but later developed a sore throat, shivered, and was found to have a temperature of $102^{\circ} \mathrm{F}$. $\left(38.9^{\circ}\right.$ C. $)$. A slight cough and nasal symptoms followed and the moderately severe headache persisted. On examination the same day she did not appear very ill. She had a slight redness of the palpebral conjunctivae and red throat with some oedema. Her cervical lymph nodes were moderately enlarged and slightly tender. Her nose was blocked, but there were no abnormal signs in the chest and she had no neck stiffness. Coxsackie B3 virus was isolated from a throat swab. Her temperature fell gradually, and by the fifth day she felt quite fit. Examination at that time revealed a moderately red pharynx, with two greyish plaques, $2 \mathrm{~mm}$. in diameter, on the soft palate, which was otherwise normal. Family History:-Her only sister had 
a similar illness, with onset two days later. Coxsackie B3 virus was isolated from her throat swab. Her mother and father remained well.

\section{Epidemiological Observations}

The first two cases of Coxsackie infection occurred in the latter half of May, 1958-one in association with an adenovirus, type 4 . From mid-June onwards cases were frequent, but the incidence appeared to be lessening before observations were interrupted in late August; no further isolations were made during the remaining period of the survey (see Chart). Therefore all Coxsackie virus
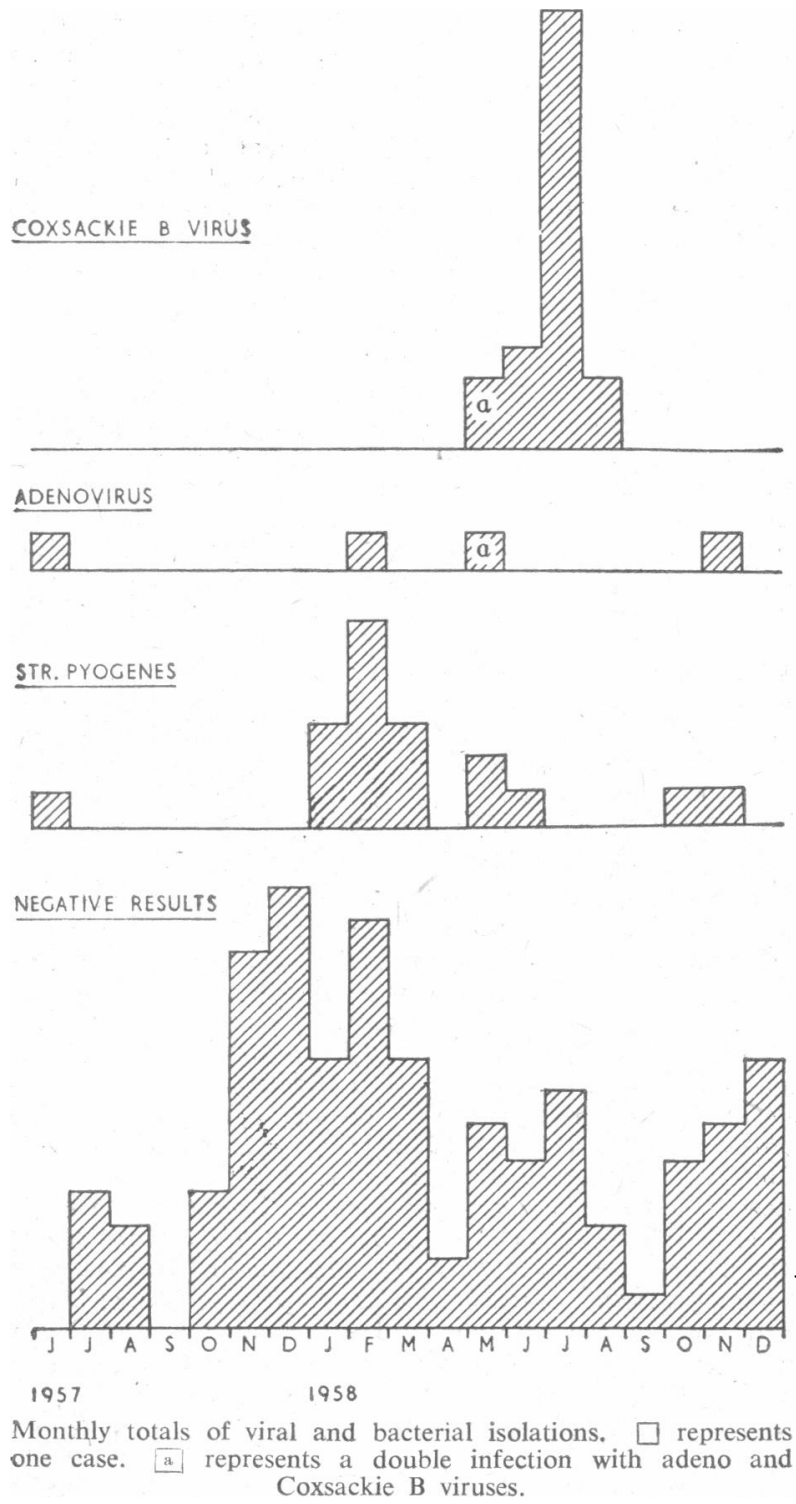

isolations were made during a period of about 12 weeks, in which 20 out of 39 throat swabs examined were positive. During the last six weeks of this period, when Coxsackie virus was isolated from 12 of 20 patients, swabs were taken from the throats of 22 children who presented with illnesses other than febrile respiratory infcctions. These were tested for Coxsackie virus with negative results. There was thus a positive correlation between febrile respiratory illness and Coxsackie virus isolation.

During the epidemic there were 19 cases from which virus was not isolated. In most of these pharyngitis was the predominant clinical feature. No cases of meningeal involvement, other than that reported above, were seen among children or adults in the general practice.

Coxsackie virus was isolated from more than one individual in each of three families, the intervals between onset of the two illnesses being 0,2 , and 4 days respectively. A limited exposure to infection, from which the incubation period could be defined more precisely, was not observed, but the intervals given would be compatible with the usual incubation period, which is assumed to be from two to four days (Rhodes and Van Rooyen, 1958).

Fourteen families in which at least one isolation of Coxsackie $B$ virus had been made were followed up. They totalled 65 individuals ( 30 adults and 35 children), of whom 4 adults and 20 children became ill. The attack rates based on clinical illness were therefore $13 \%$ and $57 \%$ respectively. In these families, 51 persons $(30$ adults and 21 children) were exposed to a primary case of Coxsackie B virus infection ; 10 febrile illnesses occurred (four among adults and six among the children), indicating a secondary attack rate of $20 \%$.

\section{Adenovirus Isolations}

Adenoviruses were isolated from children aged 1, 5, 6 , and 8 years of age (types $2,3,1$, and 4 respectively). These infections occurred at widely separated intervals (see Chart). The type 2 and type 3 infections were associated with a moderately severe illness with fever of five and four days' duration respectively, and both children had enlarged cervical glands and moderate inflammation of the throat; one of them also had a cough. Conjunctival redness was not more than that seen in many other upper respiratory infections. In the case from which type 1 virus was isolated, fever was observed to last only 24 hours. The patient had a moderately sore throat and headache, with a slight follicular exudate in the throat and tender cervical glands. In the case from which both a type 4 virus and Coxsackie B3 virus were recovered the illness started with sudden inflammation of the left eye, followed by involvement of the other eye. Oedema and follicle formation occurred in the lower palpebral sacs, with inflammation also over the bulbar conjunctivae. Slight changes in the throat, with fever, moderate cervical-gland enlargement, and preauricular-gland enlargement followed.

\section{Bacterial Infections}

The majority of Str. pyogenes isolations occurred during the period January to March, 1958, during which time 12 out of 41 swabs examined were positive. The predominant feature of the illness was pharyngitis, and, although the rest of the upper respiratory tract was usually involved to some extent, abnormal signs were not found in the chest. The throat changes were, on the whole, more severe than those seen in other infections during the survey. Follicular exudate occurred in the throats of one-third of the streptococcal cases, and tender, moderately enlarged upper anterior cervical glands were found in one half. Table II shows that most of the other clinical features were similar to those found in a group of undifferentiated respiratory infections.

Pneumococci were isolated in heavy culture from 25 cases occurring at irregular periods throughout the survey. There was thus no well-marked epidemic, and there was no consistency of type among eight strains tested (four of type II, one of type III, and three not of 
types I, II, or III). In 7 out of 22 controls pneumococci were also found in heavy culture. Analysis of signs and symptoms did not show any distinctive clinical features in these infections. For these reasons we were unable to determine their aetiological significance.

\section{Discussion}

The number of respiratory illnesses recorded in our group of children was much lower than that found by Lidwell and Sommerville (1951) in a rural community, or that of Badger, Dingle, Feller, Hodges, Jordan, and Rammelkamp (1953) in a group of volunteer families. In those surveys, however, a regular inquiry was made week by week for the occurrence of respiratory infections. We relied upon our patients or their parents reporting illness to us when it appeared to them to require advice or treatment, and in our community it is probable that many of the less serious infections were not investigated.

In general an aetiological diagnosis of these illnesses could be deduced but seldom on clinical grounds alone. Table II shows that there were differences in the incidence of symptoms and signs between the groups of illness we were able to separate, but these differences could not be relied upon in any one case. Infection due to Str. pyogenes was correctly diagnosed most often, but cases occurred from which pneumococci, adenovirus or Coxsackie B3 virus were isolated when the clinical picture had suggested a streptococcal infection. Cases of myalgia were seen in the early part of the epidemic of Coxsackie B virus infections, and in some of these the diagnosis was confirmed by virus isolation. The clinical picture of a febrile pharyngitis associated with this agent became clear, however, only in retrospect.

Among the remainder of the illnesses a few fairly well defined syndromes could be discerned. Cases of febrile coryza and febrile bronchitis similar to those found in association with the haemadsorption myxoviruses by Parrott, Vargosko, Luckey, Kim, Cumming, and Chanock (1959) were not uncommon. Several cases of fever, lasting up to seven days, with enlargement of the cervical glands, but few other signs or symptoms suggesting glandular fever, were also seen. Short fevers with prominent constitutional symptoms and a rash resembling roseola infantum occurred from time to time throughout the survey. These observations suggest that further differentiation of acute respiratory illness on clinical grounds may yet be possible. Such advances will depend on the continued application of laboratory techniques to these problems.

Since their discovery by Dalldorf and Sickles (1948) Coxsackie viruses have been shown to be associated with a variety of clinical syndromes. In particular, Coxsackie $B$ viruses have caused epidemic myalgia, aseptic meningitis, and mild pharyngitis. More recently they have been found to give rise to a severe and sometimes fatal myocarditis in infants (Javett, Heymann, Mundel, Pepler, Lurie, Gear, Measroch, and Kirsch, 1956). Infection with these viruses, which are usually only moderately severe, may thus be of considerable importance in a community, especially within the family.

During epidemic periods of Coxsackie infection the virus may be isolated from the faeces of many apparently healthy persons, particularly children. It may therefore sometimes be difficult to assess the aetiological significance of the presence of Coxsackie virus in the faeces of a clinical case. Virus is present in the throat probably for a short time only during illness.
For this reason, and also because virus was not isolated from the throats of control children examined during the epidemic period, it seems likely that in those of our patients from whom virus was recovered it was the -cause of the observed illness. This conclusion is supported by the occurrence of a fourfold rise of titre in the one patient from whom paired sera were tested for neutralizing antibodies.

Accounts of epidemics due to Coxsackie B virus have generally stressed the occurrence of one type of illness, either myalgic or meningeal (Warin, Davies, Sanders, and Vizoso, 1953 : Rubin, Lehan, Doto, Chin, Heeren, Johnson, Wenner, and Furcolow, 1959). Gordon, Lennette, and Sandrock (1959), in a review of this subject, conclude that age may be a possible factor in determining the type of disease. At the same time they refer to the variety of clinical manifestations which may be present during an epidemic. Pharyngitis predominated in our own cases, which were similar to those described in a family outbreak by Jordan, Stevens, Katz, and Dingle (1956).

Our cases occurred at a time when Coxsackie B virus infections were prevalent in many parts of the country. In West Surrey this virus was isolated from a number of patients with an illness resembling non-paralytic poliomyelitis (Cook, 1959), though none of these came from the general practice investigated. Most of these patients were admitted to hospital with a moderately severe illness. Possibly the milder type of disease seen in our cases was more representative of the common response to infection with this virus.

In our survey the isolation rate for adenoviruses was similar to that found by Jordan, Badger, Curtiss, Dingle, Ginsberg, and Gold (1956). It is not clear whether such sporadic infections are responsible for the antibodies that are known to occur in young adults (Huebner, Rowe, Ward, Parrott, and Bell, 1954 ; Stovin, 1958), or whether these antibodies are mainly caused by recurrent epidemics and subclinical infections. Type 4 adenovirus is an unusual type to be encountered in childhood, as most isolations have been made in military populations. However, van der Veen and van der Ploeg (1958), in the Netherlands, described an outbreak of pharyngoconjunctival fever in children, part of which was due to this type.

It is known that adenovirus types 1 and 2 are common latent viruses in young children. In the absence of tests for complement-fixing antibodies or of control studies, it is difficult to assess the aetiological significance of the four strains isolated.

Using a comparatively simple technique, we were able to isolate a potential pathogen in $28 \%$ of our cases. HeLa cells, however, are not suitable for the isolation of Coxsackie A viruses or for most of the haemadsorption myxoviruses such as cause acute respiratory disease in children. No doubt the proportion of illnesses identified as viral infections would have been higher if serological tests, stool culture, and a less restricted virological technique had been employed.

\section{Summary}

Acute respiratory infections occurring among children up to 18 years of age, in a general practice, were investigated by clinical, bacteriological, and virological methods. 146 illnesses were investigated among a group of 595 children over the period June 1, 1957, to December 31, 1958. 
In $41(28.1 \%)$ of the illnesses investigated, one or more pathogens were isolated from throat swabs.

Nineteen isolations of Coxsackie B3 virus and one of Coxsackie B4 virus were made over a period of 12 weeks during the summer of 1958 . Most patients suffered from a febrile pharyngitis, but two myalgic and one mild meningeal illness also occurred. This epidemic coincided with an increased prevalence of Coxsackie B3 virus infection in West Surrey.

Four adenoviruses of types 1 to 4 inclusive were isolated, associated with three illnesses characterized by pharyngitis and lymphadenopathy and one by pharyngoconjunctivitis.

Str. pyogenes was isolated 18 times. Pharyngitis more severe than that seen in any other illnesses at the time, with some involvement of the upper respiratory tract, characterized these infections.

Though the frequency distribution of particular symptoms varies to some extent in the different infections, it is clear that in the individual patient a clinical diagnosis of the infecting agent cannot be made with certainty. Further knowledge of the aetiology of these upper respiratory infections can come about only by close collaboration of the medical practitioner with the laboratory.

During the investigation, typing of Coxsackie B viruses and adenoviruses was kindly carried out by Dr. A. J. H. Tomlinson, Bacteriological Laboratory, County Hall, London, and by the Virus Reference Laboratory, Colindale. We are also grateful to Dr. N. Richardson, Pathological Laboratory, Epsom District Hospital, for organizing facilities for storage and transport of frozen specimens; and to the Distillers Company Limited, Great Burgh, Epsom, for supplies of "cardice."

\section{RBFERENCES}

Badger, G. F., Dingle, J. H., Feller, A. E., Hodges, R. G., Jordan, W. S., jun., and Rammelkamp, C. H., jun. (1953). Amer. J. Hyg., 58, 31

Cook, G. T. (1959). Monthly Bull. Minist. Hlth Lab. Serv., 18, 138.

Dalldorf, G., and Sickles, G. M. (1948). Science, 108, 61.

Gordon, R. B. Lennette, E. H., and Sandrock, R. S. (1959). A.M.A. Arch. intern. Med., 103, 63.

Huebner, R. J., Rowe, W. P., Ward, T. G., Parrott, R. H., and Bell, J. A.' (1954). New Engl. J. Med., 251, 1077.

Javett, S. N. Heymann. S., Mundel, B., Pepler, W. J., Lurie H I Gear, J., Measroch, V., and Kirsch, Z. (1956). J. Pediat., 48, 1 .

Jordan, W. S., jun., Badger, G. F., Curtiss, C., Dingle, J. H., Ginsberg. H. S., and Gold, E.' (1956). Amer. J. Hyg., 64, 336.

Stevens, D., Katz, S., and Dingle, J. H. (1956). New Engl. J. Med., 254, 687.

Lidweli, O. M., and Sommerville, T. (1951). J. Hyg. (Camb.), 49, 365

Logan, W. P. D., and Cushion. A. A. (1958). General Registe Office: Studies on Medical and Population Subjects, No. 14: Morbidity Statistics from General Practice, vol. 1 (General). H.M.S.O., London.

Maxted, W. R. (1953). J. clin. Path., 6, 224.

Parrott, R. H., Vargosko, A., Luckey, A., Kim, H. W., Cumming, C., and Chanock, R. (1959). New Engl.J. Med., 260, 731.

Rhodes, A. J., and Van Rooven, C. E. (1958). Textbook of Virology, 3rd ed. Baltimore.

Rubin, H., Lehan, P. H., Doto, I. L., Chin, T. D. Y., Heeren, R. H., Johnson, O., Wenner, H., A., and Furcolow, M. L. (1958). New Engl. Jै. Med., 258. 255

Stovin, S. (1958). J. Hug. (Camb.), $36,404$.

Veen. J. van der, and Ploeg, G. van der (1958). Amer. J. Hyg., 68, 95 .

Warin, J. F., Davies, J. B. M., Sanders, F. K., and Vizoso, A. D. (1953). Brit. med. J., 1, 1345.

Requirements for Halsted's mosquito artery forceps (stainless steel, nominal overall length 47 in.) are specified in a new British Standard (B.S. 3246:1960). Copies of this standard may be obtained from the British Standards Institution, Sales Branch, 2, Park Street, London, W.1. Price 4s. (Postage extra to non-subscribers.)

\section{IS UNIVERSAL VACCINATION AGAINST PERTUSSIS ALWAYS JUSTIFIED?}

BY

JUSTUS STRÖM, M.D.

From the Hospital for Infectious Diseases, Stockholm, Sweden

Pertussis is still a great child-killer in many countries. Effective vaccines are now available, but are not devoid of risks, especially of a neurological nature. In some countries-for example, Sweden - the illness has assumed increasingly mild forms and the mortality is now very low. Thus the situation may arise when we must weigh up the relative advantages and disadvantages of vaccination.

There is no doubt that the new vaccines are very effective against pertussis. The British Medical Research Council reported in 1951 that cases of pertussis had been reduced to about one-fifth. Similar results are reported from the U.S.A. The new Swedish pertussis vaccine, which is given as a triple-vaccine (alum-precipitated) against diphtheria, tetanus, and whooping-cough, is prepared on modern principles (Arvidson and UllbergOlsson, 1952). It has good serological action (Ericsson et al., 1952 ; Vahlquist et al., 1954 ; Laurell et al., 1957). The effect of its application to the community compares favourably with that produced by the best foreign vaccines (Rabo, 1956).

Neurological Complications after Pertussis Vaccination

The earliest report of neurological complications after pertussis vaccination came from Denmark (Madsen, 1933). Other isolated instances were published later, but the first really alarming report came from the U.S.A. when Byers and Moll (1948) described 15 severe cases; two of the patients died. All of those who recovered showed persistent convulsions, seven were mentally retarded, five had a hemiplegia, and two were blind. Toomey (1949) thereafter addressed a questionary to paediatricians in the U.S.A. ; 54 answered and reported 38 cases of convulsions with 2 deaths and 12 irreversible cerebral lesions. In Switzerland, Köng (1953), who had himself observed one death and one case of convulsions accompanied by hemiplegia, reported 82 cases known up to 1951. Halpern and Halpern (1955) sent out a new questionary in the U.S.A., and received 56 replies reporting 15 cases of convulsions with one death and three irreversible lesions. Relatively speaking, the situation appeared to have improved, and this was attributed to the higher degree of purity of the vaccines.

In 1958 Berg reported on a personally observed case (convulsions and progressive dementia), which was the seventh from Great Britain. Berg collected data on 108 cases. Many different types of vaccine were implicated ; the reactions might occur after any of a series of inoculations, but were more common after the first or second; the interval between vaccination and onset of reactions was usually brief. There were 15 deaths. Thursby-Pelham and Giles (1958) reported six cases (one of which had been included in Berg's series), Andrews (1958) two, and Leigh (1958) and Jones (1958) one each.

Soon after the introduction of triple vaccination on a large scale in Sweden in the mid-'fifties, suspect cases of severe vaccination reactions came to our knowledge. Consequently, at the end of 1958 a questionary was addressed to all 36 children's hospitals and to all 28 